ESJ Social Sciences

\title{
Albania: Motivation Factors Among 15-Year-Old Students, Especially Disadvantaged Ones
}

\author{
Gentiana Sula \\ PhD Candidate
}

\section{Doi:10.19044/esj.2021.v17n15p57}

Submitted: 21 April 2021

Accepted: 12 May 2021

Published: 31 May 2021
Copyright 2021 Author(s)

Under Creative Commons BY-NC-ND

4.0 OPEN ACCESS

Cite As:

Sula G. (2021). Albania: Motivation Factors Among 15-Year-Old Students, Especially Disadvantaged Ones.

European Scientific Journal, ESJ, 17(15), 57. https://doi.org/10.19044/esj.2021.v17n15p57

\begin{abstract}
The importance of the study lies in the analysis of youth productivity and employment. From the data so far it is underlined that the potential of Albanian youth will be realized only for $56 \%$ if no measures are taken. Referring to the literature review, there is a division of scholars' attention towards vocational education and employment or secondary and higher education, without emphasizing the potential of basic education in guiding the student towards clarity. In other words, they do not stimulate students' motivation towards a certain profile. The article is based on mainly secondary data analysis. The pourpose of this article seeks to verify some motivation factors among 15-year-old students, especially disadvantaged ones, for instance the attitude toward learning, access to books, and the reach of career guidance services in basic education schools in Albania. Some conclusions from the data analysis show that in the circumstances of youth unemployment, the motivation to perform better among 15-year-old students may be more related to seeing success and being more productive at work. Albanian students show little vision of their future careers, especially the most disadvantaged. Factors that can influence the growth of students' career goals can be: their attitude towards books and reading, school choice and access to career guidance services in schools in Albania.
\end{abstract}

Keywords: Attitudes, Lockdown, Quarantine, Isolation, COVID-19, Risk, Predictor 


\section{Context}

Literature confirms the connection between the visions of tomorrow's world of work with the position of the student toward learning, starting from basic education. For instance, it is established that students learn better if they have a strong motive and clarity about their future and the path they want to undertake as adults. In order to measure learning, there is broad consensus that its strongest predictor is the very level of reading comprehension at 15 years old, which OECD measures every three years through the PISA international test.

There are several theories about learning motivation, but this article will focus on the expectancy model (P.H. HemaMalini, 2014), which connects efforts with expectations and the redard deriving from productive employment. This model has been used first for motivating workers, but then it expanded to motivation for learning.

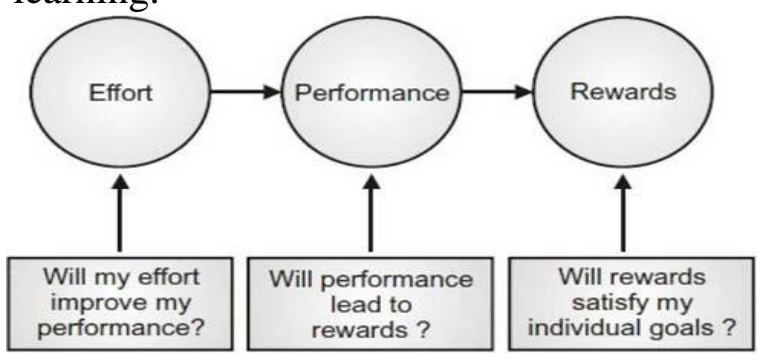

Source 1. https://positivepsychology.com/motivation-education/

With regard to results on reading, the connection with three preconditions is verified and these are the social-economic background (consisting of parents' education, their employment, and the writing-reading home environment); school and the educational environment, as well as the student profile with the skills, efforts, and motivation (Cordula Artelt Jürgen Baumert Nele Julius-McElvany, 2003).

The 2013-2018 Government of Albania Program made young unemployment a priority to address. The vocational skills gap for young people was highlighted in itself as a cause for low productivity of individuals in Albania and a slowdown of growth in the private sector (National Strategy for Employment and Skills, 2014). In this context, it was documented that the socially most vulnerable groups were farther from access to specialized services, such as: students without basic education, Roma and Egyptian children, girls and particularly those who were victims of abuse and trafficking, as well as youth who did not have access to to choosing vocational schools due to distance from services. Another factor was the gender stereotype about vocational work and education that kept girls away from such service and closer to work at home. 
Meanwhile, a clearer employment perspective motivates children's learning at very young ages and improves their attitude toward school. However, this perspective is not clear for groups of disadvantaged ${ }^{1}$ children. In Albania, only $4 \%$ of 15 -year-old disadvantaged students who are PISA participants have a clear idea of what they want to become when they grow up, ranking last among the 78 countries that participated in the testing. ${ }^{2}$ Furthermore, literature confirms a strong connection between students' access to learning and the achievement of student results, thus providing an indicator that is interdependent upon the choices the student will make in life. For instance, students who show greater interest in reading or those who are more capable of resolving difficult problems are more likely to perform better. Also, particularly strong connections appear between the tendency of students to control their learning consciously to monitor progress and their selfconfidence. This suggests that effective learning may not be acquired simply as a skill, but it also depends greatly on the development of positive attitudes toward learning as a process (Cordula Artelt Jürgen Baumert Nele JuliusMcElvany, 2003).

Another theory that connects learning with the perspective of productivity in adult life for any individual is that of human capital. This encompasses: "The skills, knowledge, and experience possessed by an individual or population, seen in connection with their value or cost for an organization or country" (Dictionary.com, 2021). Different theories are at use to define human capital. Human capital is also measured by the World Bank (Human Capital Project, 2021) and the United Nations Organization (Guide on Measuring Human Capital, 2016) in approximate manners, but the definition according to the World Economic Forum (World Economic Forum, 2017), has drawn attention because it defines the productivity of a person or society in its dynamics, without circumventing the factors that diminish such capital, such as unemployment or lack of productivity.

Albania's human resources index is evaluated at 58.2 by this measurement. The analysis of each component confirms achievement in the length of schooling (years of school and growing participation), but when it comes to effectiveness in educational attainment (math and functional reading), employment (number of youths at work) or complex and specialized skills, Albania ranks at particularly low and declining levels. This means that unless active and effective policies are undertaken, an Albanian child is expected to develop only 58 percent of its potential when he/she grows up.

\footnotetext{
${ }^{1}$ According to OECD, 25\% of students with lower social-economic and cultural index are considered disadvantaged.

${ }^{2}$ https://gpseducation.oecd.org/CountryProfile?plotter=h5\&primaryCountry=ALB\&treshold $=5 \&$ topic $=\mathrm{PI}$
} 
Thus, the conclusion may be drawn that a priority is not only the increase in the first dimension, which has to do with high school attendance indicators, but this capital should not be undone by lack of its use immediately after school. This may occur if access to the labor market is obstructed or attained vocational skills are not appropriate or compatible with labor market needs.

\section{Methodology}

The article is based on mainly secondary data analysis. The following reflects the purpose and objectives of the study and supports the selection of literature review and a cross-sectional analysis through secondary data, as well as the limitations of the study.

The purpose of this article seeks to verify some motivation factors among 15-year-old students, especially disadvantaged ones, for instance the attitude toward learning, access to books, and the reach of career guidance services in basic education schools in Albania.

First objective of the article, offer a review of the literature will abstract a conceptual framework of factors that affect the motivation of 15year-old students for learning and the future of their careers.

Second objective, the analysis of secondary data (source INSTAT) will give us a description of the progress of youth employment for the years 20142020, seen from the aspects of demographic change.

Third objective, cross-sectional analysis through data collected from OECD standardized questionnaires in the PISA 2018 test. The indicators are as follows:

a) Students' access to learning and books;

b) School selection;

c) Efficiency of career guidance services in 9-year schools.

The article aims to draw on existing data to analyze some elements that are directly related to students' aspirations and motivation, as well as the role of schools or employment services in this field. To get a more complete picture, the article will use data collected through the OECD during the PISA 2018 test. Regarding the sample size: Albania is represented in the PISA 2018 program by 327 schools and 6,359 students.

Figure 1 (presents a conceptual model of the factors that influence student motivation. It includes different factors in this model, but the focus will be only on the factors of access to learning and career guidance services among 15-year-olds). 


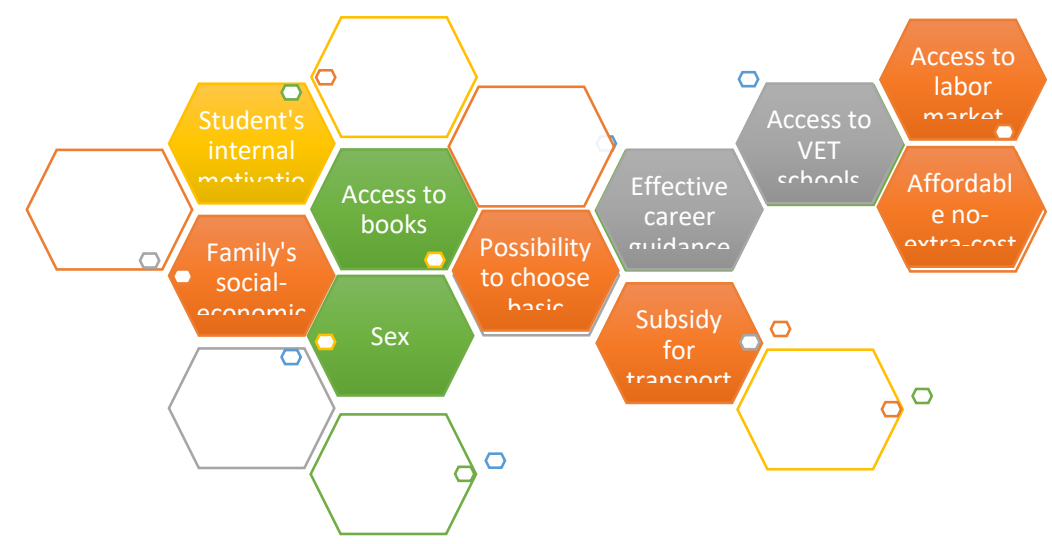

Figure 1. Schematic presentation of factors linked with moditavion of 15-year-old students in Albania, 2018

\section{Population and sampling}

The target population consists of 15-year-old students who have been selected to be inclusive in terms of sex, place of residence, social-economic status, etc., aiming at the $9^{\text {th }}$ and $10^{\text {th }}$ grades, and plans to include full-time as well as part-time students, and even students who attend vocational programs or other similar programs, foreign students who attended foreign schools in their own countries, as well as foreign students who attend relevant education in Albania. The entire information used and analyzed in this research has been obtained from questionnaires prepared for different target groups that include: questionnaires for students, teachers of Albanian, and school administrators referring to the database created by PISA 2018. ${ }^{3}$ The article has processed only the data on the students. PISA was created and developed as a program by the Organization for Economic Cooperation and Development (OECD) at the end of the 1990s as continued, international comparative study, which collects mainly the indicators of student characteristics and skills. PISA also collects contextual data that allows these results to be interpreted in terms of their broader contexts. Data from PISA are of interest to academia, researchers, and other partners in education. ${ }^{4}$

\section{Sample of students}

With regard to the sample of students, ${ }^{5}$ the sample selected for Albania consists of 6,359 students of the 15-year old age group from a population of

\footnotetext{
${ }^{3}$ https://www.oecd.org/pisa/data/2018database/

${ }^{4}$ CY7_1703_GEN_NPMManual_FULL_1.docx 8

${ }^{5}$ https://www.oecd.org/pisa/data/2018database/CY7_201710_QST_MS_STQ_NoNotes_fina l.pdf
} 
30,160 students (15-year old students enrolled in schools). ${ }^{6}$ A series of components were taken into consideration while selecting the students, such as: sex, class, type of school, etc. Their division is as follows:

The questionnaire of students focuses mainly on:

- The student, his/her family, and home;

- Language learning at school;

- Views on reading;

- What the student thinks about life;

- About school;

- School hours and time spent on learning.

The limitations of the research stem from the fact that the collected information is based on self-reporting, which may often contain doses of subjectivity. Another limitation has to do with the statistics on employment in villages, which underestimate the phenomenon because they consider villages as entirely employed in agriculture. Nevertheless, information is very valuable and the sampling is credible.

\section{Findings}

\section{Dynamics of the political and institutional framework of laws and employment policies}

In keeping with the vision of the European Union "Europa 2020” and accession requirements for Albania to this body, Albania focused on employment relying on enabling our workforce and guiding it toward the needs of the labor market (https://www.cedefop.europa.eu, n.d.). This political action sought to considerably improve the system of services for jobseekers and to bring the vocational education system closer to these services. ${ }^{7}$ The goal was to achieve this through forming a unified system of employment services based on best European practices. Vocational training and employment were seen as limbs of the same body, seeking the connection between the two, with dual education being the leading word. The reform was accompanied by legal reforms, amending and improving the Labor Code, ${ }^{8}$ so that it would allow for room for paid internships for young people, which were not even mentioned in this Code in the past. Beside the Code, the entire Law on Vocational Education was redone in order to allow for the transformation of vocational high schools into multi-disciplinary lifelong training centers, and

${ }^{6}$ Table 11.1, Population characteristics, sample characteristics, exclusions and coverage indices for countries/economies, https://www.oecd.org/pisa/data/pisa2018technicalreport/

${ }^{7}$ Act no. 63/2014 on some amendments to law no. 8872, dated 29.3.2002, “on vocational education and training in the republic of albania," amended

${ }^{8}$ Act no. 7961, dated 12.7.1995, labor code of the republic of albania (amended by laws: no. 8085, dated 13.3.1996; no. 9125, dated 29.7.2003; no. 10 053, dated 29.12.2008; no.

136/2015, dated 5.12.2015) 
create opportunities for founding higher vocational schools ${ }^{9}$. The higher education law contained provisions for a more complete implementation of the National Qualification Framework ${ }^{10}$ and the National List of Occupations, ${ }^{11}$ and with them, a package of by-laws was drafted that articulated this reform at the institutional level. Investments accompanied the essential changes of transforming employment offices and employment programs, ${ }^{12}$ which targeted particularly underemployed groups such as women and young people.

In the process, another goal emerged for strengthening ties between learning and facilitating the transition to jobs. To that end, vocational education and training services were seen seen as closely linked together with the final goal being employment. The interconnection between school curricula with wellorganized practice or internships in the workplace, using elements of the German dual system approach, gave the opportunity for vocational education to those young people who were neither at school nor at work and who, according to the living standard measurement by INSTAT in 2012, were at an alarming level of 30 percent in 2013.

The other benefit was seen in coordination with the private sector, which is also the provider of jobs. Thus, in every vocational school, entrepreneurs of the relevant areas were invited to assume leadership positions in the boards. Such instances were notices for instance in the Construction school, whereby a leading construction company assumed leadership of the board, or the tourism school, where another company from this sector assumed leadership, etc. A new vocational school was also created with the help of donors in the field of ICT.

\section{Groups at risk of of exclusion from the labor market}

As in every country, student achievement in Albania depends directly from the social-economic status of parents, their geographic location, sex, and social-cultural affiliation, e.g. minorities. These have a direct impact on school results as well as the opportunities of individuals for employment and selfrealization.

Both of these groups have lower educational results. The very gap of results between villages and the cities is by 38 points according to PISA 2018 (achievements of one year), while the one between lower and higher social-

${ }^{9}$ for the first time, The Higher Education Act defined provision of higher vocational education

${ }^{10}$ Act no. 23/2018 on some amendments and additions to law no, 10 247, dated 4.3.2010, "on the albanian framework of qualifications"

${ }^{11}$ Council of Ministers Decision no. 514, dated 20.09.2017 on the approval of the national list of occupations (nlp)

${ }^{12}$ Council of Ministers decisions on Employment Programs 
economic groups is 60 points (achievements of two years). With regard to regions, the article finds that educational results are lower in the north, then the south, and then the middle of the country.

Nevertheless, the average results of disadvantaged groups and those in the villages suggest such poor results that they do not ensure access to higher education and, therefore, to employment with satisfactory salaries, suggesting even lower motivation among these groups. Meanwhile, an opinion survey organized by Friedrich Ebert in Albania suggests that $82 \%$ of youth point to the salary as the leading motivation for their employment.

Inhabitants of rural areas (30\% declared as such) have limited access to employment and vocational education and training services due to distance from specialized services, but also due to the nature of their activity, which is often a closed economy working mostly to fulfill survival needs and not participating actively in the market. Although the term used officially is selfemployed, in fact, there is evidence that the situation in villages looks more like under-employment. The International Labor Organization (ILO) made clear that about 300,000 village inhabitants in Albania at present are occupied with work, however, not being paid for their work, they do not pay social and health insurance and they do not pay any taxes. The goal to start with interventions with mobile employment and vocational training services was not realized. Vulnerable groups, such as women, youth, persons with disabilities, the Roma and Egyptians, etc., have limited access to employment and vocational training services. Special employment programs were designed to allow for internships in the workplace through public funds.

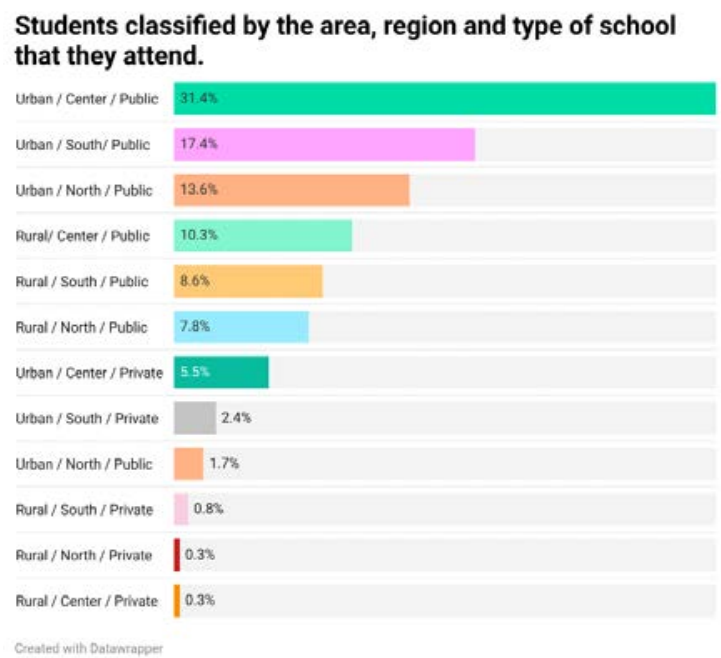

Figure 2. Students clasiffied by the area, regin and type of school they attend 
The adaptation of these services toward the needs and capabilities of these groups was at the focus of this strategy. However, the continuity of these services and the full coverage of all groups in need remains a challenge. A distribution of students selected by PISA may be found in Fig. 3, which indicates that about 30 percent of the student population is in the villages, according to their own declarations.

\section{Youth employment in Albania}

Youth employment remains a priority for a society like Albania, which has a relatively young age. In Albania, the average age on January 1, 2020, was 37.2 years, and the youth age group (15-29 years old) on January 1, 2020, was 23.2 percent of the population. In the last 5 years, the number of the youth population has dropped by 54,950 individuals, although the article finds that the 25-29 age group has increased by 12,902 individuals.

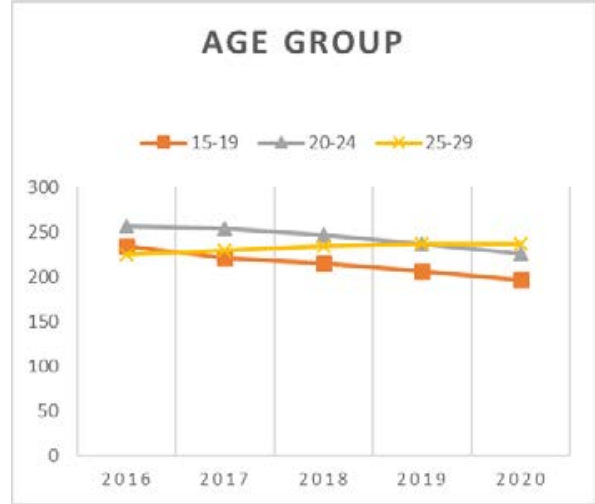

Figure 3. Age demografic status 2016-2020, source INSTAT 2020

\section{Result in unemployment today?}

According to the Labour Force Survey 2020, measured by INSTAT, the article finds this growing tendency of the level of employment, with a higher increase among youth age groups. (Fig 4).

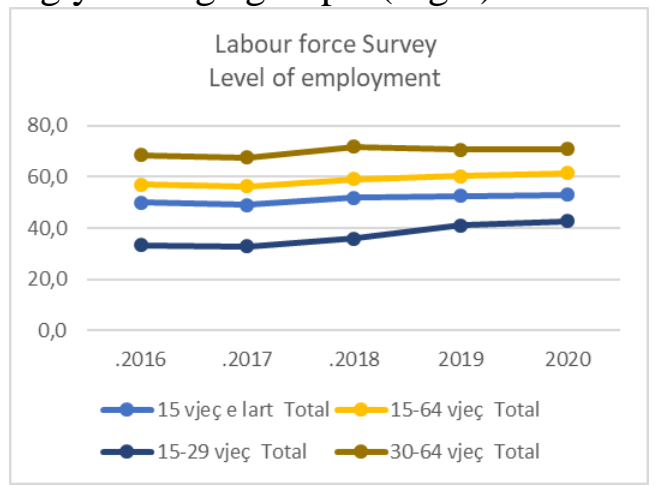

Figure 4. Level of employment 
Figure 3, built on data from the Labour Force Survey collected by INSTAT for 2016 until 2020, looks at unemployment tendency by sex.

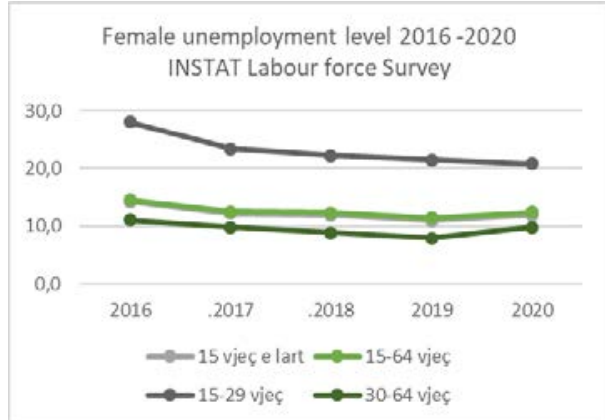

Figure 5. Female unemployment level 2016-2020, LFS 2020

The article finds that the reduction of unemployment among women and girls appears more enhanced in the 15-29-year-old age group, although this age group has a slight demographic growth.



Figure 6. Male unemployment level 2016-2020, INSTAT LFS 2020

At the same time, a look at the level of unemployment among males also indicates a decrease (fig. 4), but the decrease is mainly seen in the 15-29 years old age group category. The same tendency is seen in employment figures, whereby (fig. 6) there is a more evident growth in 15-29 years old age groups.

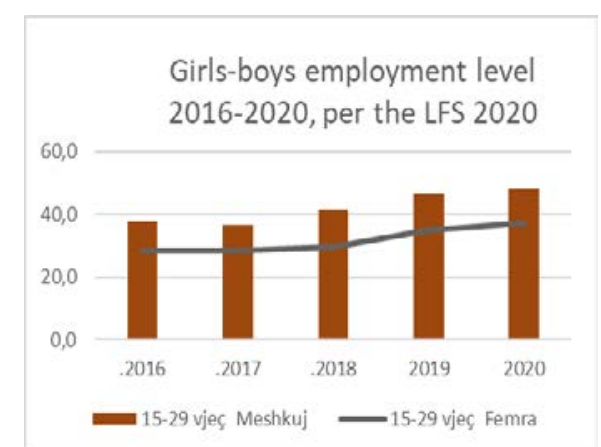

Figure 7. Girls-boys employment level, LFS 2020, 2016-2020 
From a gender perspective, the article finds a slight increase of employment among both sexes, while the gender gap in employment remains, in favor of boys.

The increase of youth employment is particularly seen after the expansion of employment through call-center and made-to-order production, which are mostly located in urban areas. Nevertheless, surveys conducted by Friedrich Ebert in Albania suggest that $48 \%$ of youth do not work in the field of education they received, while $36 \%$ work at a level lower than the education they received. Meanwhile, $83 \%$ of youth think that family or friendship ties are decisive for ensuring appropriate employment.

As a result, it may be said that youth unemployment has decreased and employment for the same age has increased, while the gender gap persists.

\section{School availability as an expression of options for further education}

PISA 2018 asked students about the possibility to choose schools. As may be seen in Fig. 7, it appears that selecting a school of basic education in Albania is impossible for at least 30 percent of students. This suggests that for $30 \%$, there is no chance to seek a better schooling opportunity, that there is no healthy competition between schools, and that students of the same community do not have opportunities to socialize with students of different profiles, learn from them, and find inspiring models. Rather, they are stuck within the familiar models of expectations within their communities.

The opportunities for education of students by area.

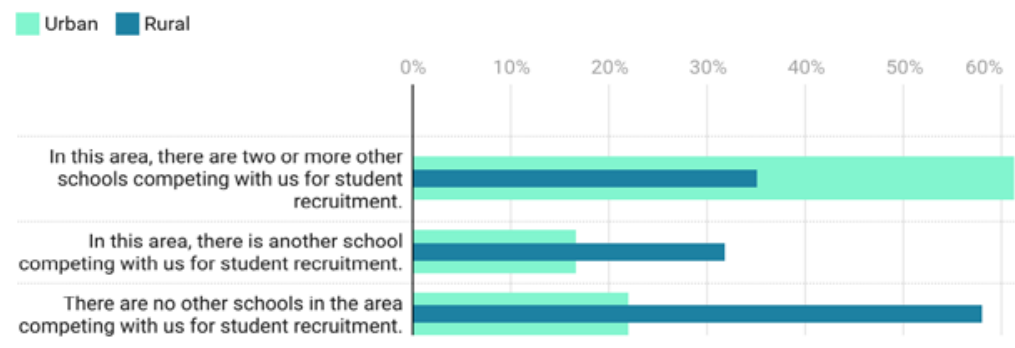

Created with Datawrapper

Figure 8. Opportunity to select school in village and city

This lack of choices suggests that the choice for vocational education or beyond it, access to higher education or employment faces an additional challenge: that of distance for students from the more remote areas. The distance of students in basic schools for those $4 \mathrm{~km}$ away has been resolved through a grant that covers transportation, but it does not appear to function for high-school ages or above. 


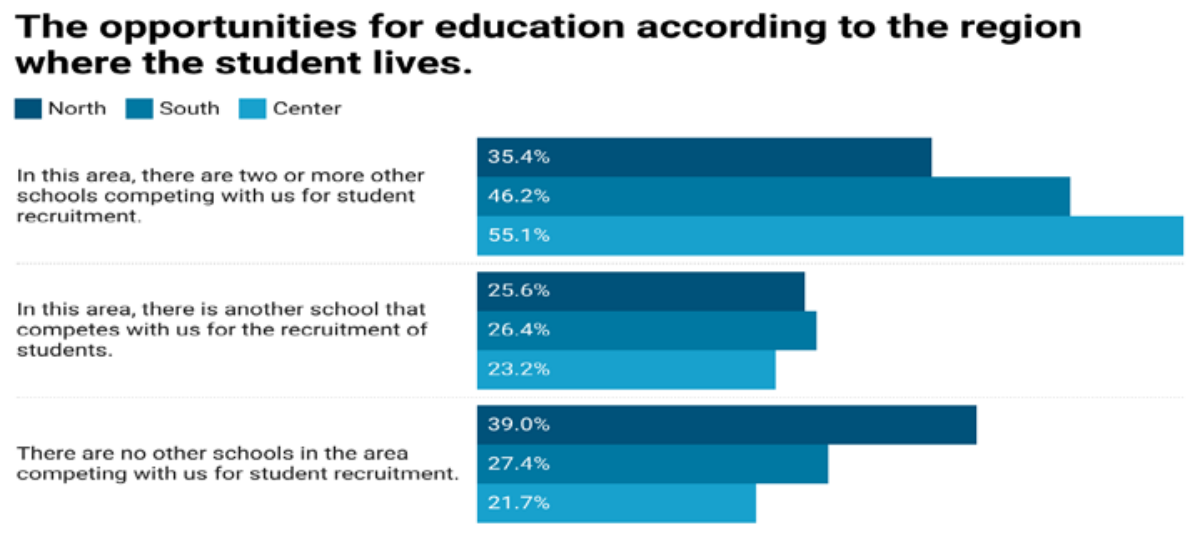

Figure 9. Opportunities for education for students by region - school choice

\section{Aspects of the attitude to learning and book reading}

Numerous research studies have argued that the attitude to learning is mostly determined by the home literacy environment. Access to books at home was selected in this research, whose value was assessed by PISA 2018.

It is confirmed that there is low access to books in the home environment, suggesting that the home literacy environment is still poor and, unless measures are undertaken, naturally achievements in reading and all other subjects will remain low and at the limits of learning poverty. Likewise, employement of these students will be only at unqualified levels, which does not allow for thriving and progress. Thus, the question of how many books do you have at home is disturbing due to the response figure of less than 10 books for about 31 percent of students, at a time when it is common knowledge that access to books has a direct correlation with educational results in every subject.

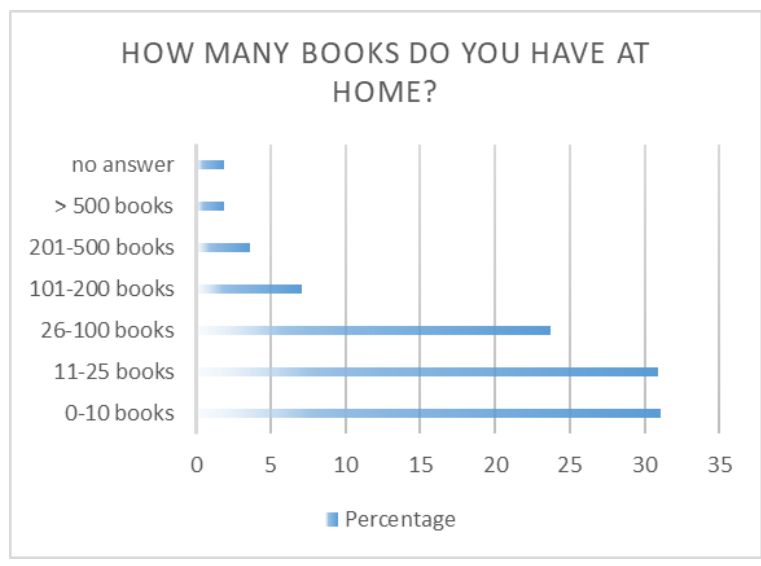

Figure 10. How many books do yo have at home? 
The same concern remains also when looking at illustrative Figure 10, which indicates how often students willingly read books, magazines, literary or informative books, with 50 percent of them reading a few times a month. Other data of interest that describe the village and city students' attitudes has to do with responses that students provided for the PISA questionnaire about obstacles to learning, found at addendum 1 . One notices there that in fact, the indicators of learning and students' attitude toward school do not have visible differences between villages and cities, which might once again confirm what literature has highlighted: that it is not the school, but rather the PEER factor that is more important in imagining success and efforts to attain it.

School career guidance

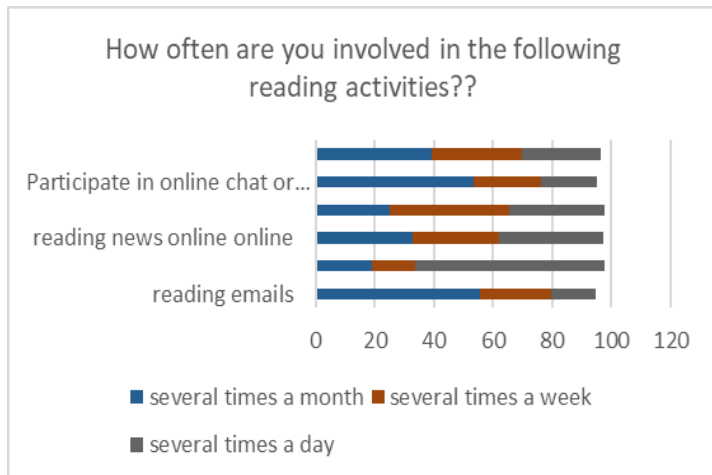

Figure 12. How often do you read the following willingly

\section{School career guidance}

Research studies have highlighted that career guidance increases student motivation and their focus for educational results. They also highlight the fact that students from disadvantaged groups benefit more from career guidance because they lack support and information. This is particularly true for balancing gender stereotype gaps in choices for further education or the labor market. The most effective way in OECD countries for doing this are professional counselors (30 percent) or special teachers trained to carry out this function (70 percent) (WORKING IT OUT: CAREER GUIDANCE AND EMPLOYER ENGAGEMENT, 2019).

On questions regarding career guidance in the $9^{\text {th }}$ and $10^{\text {th }}$ grades, students respond almost evenly to the question about the responsibility for career guidance, stressing the lack of a specialized service in this area in their schools. This activity is expected to be carried out by all teachers or one of them.

Thus, 7 percent respond that career guidance does not occur at all in schools. A significant part respond that they receive career guidance services either from specialized personnel in their schools or from mobile personnel visiting school time after time. This suggests that it is likely that this category 
belongs precisely to vocational schools serving $10^{\text {th }}$ grades, where school autonomy is a reality. Thus, 3.9 percent claim that their schools have hired career guides and 12 percent respond that they have career guides who visit their schools time after time.

The overwhelming majority of responses suggest that career service is offered by school teachers. 42 percent respond that a teacher in their school has been assigned as a career guide and 35 percent respond that all teachers provide a bit of this service.

It is worth mentioning the fact that the teacher, in the Law on PreUniversity Education is defined as the person who has earned the right to exercise the teaching profession in pre-university education, while basic schools only have room for assistant teachers and psycho-social services. It is maybe due to this reason that career guidance services are not included in training about career guidance and information on the labor market.

\section{"Who has the primary responsibility for career guidance for 9th and 10th graders in your school?"}

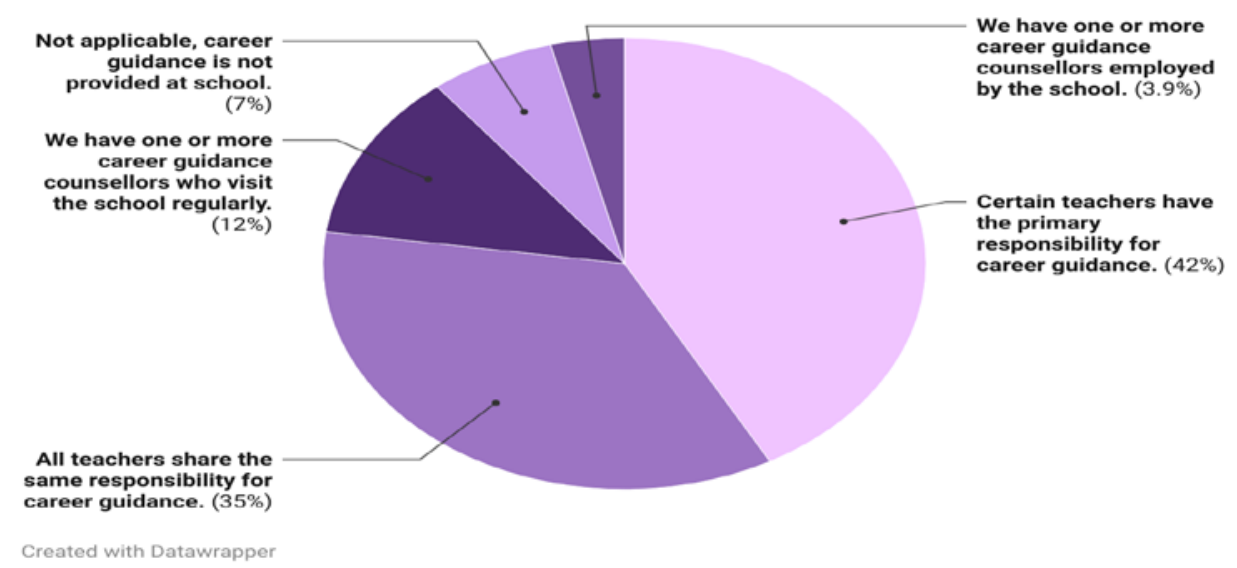

Figure 13. Career guidance responsibility in schools, grades 9 and 10, by size of community

\section{Conclusions}

1. It was noticed that the lack of choices of schools is more evident among village students, whereby 58\% declare that there are no other schools that may compete for student recruitment in the area, followed by the northern region, whereby $39 \%$ of students declare a lack of options of other schools.

2. Act on Pre-University Education and the Act on Vocational Education do not envisage career guidance services. Likewise, there are no clear provisions about this service, no mentioning of any counselor in school staffs, or regarding specialized employment services. 
3. It may be said that obstacles to learning among villages and cities are not found in schools, but particularly in the access to a reading environment at home, as well as the learning habit.

\section{Recommendations}

Based on the findings described above, the article presents the following recommendations:

1. Expansion of employment services to the villages, to ensure access for basic education and high schools, will enable development of the labor market in these areas in order for youth employment to include the villages too.

2. Expansion of specialized career guidance services in basic education schools should be accompanied by legal improvements of the definitions of self-service and should recognize the profession of the career counselor, regulating it by age groups.

3. Schools should be more active in supporting students without a home literacy environment, creating possibilities for access to books in school, particularly informative books and those of a technical nature, which would expand the horizons of students to envisage options for productive activity.

4. Deficiencies in school selection should be filled by familiarizing students in isolated localities with alternative schools, particularly those of better performance, e.g. through the creation of school networks. Distances to better, specialized schools such as professional ones as well as the general middle schools or higher ones should be overcome by providing financial facilities for transportation but also accommodation, especially for girls.

\section{References:}

1. Cordula Artelt Jürgen Baumert Nele Julius-McElvany. (2003). LEARNERS FOR LIFE, STUDENT APPROACHES TO LEARNING. Paris: OECD.

2. Dictionary.com. (2021, March 24). Retrieved from https://www.dictionary.com/

3. (n.d.). Education and Training 2020. Bruxelles: European Union.

4. (2013). Education quality and opportunities for skills development. Albania an analysis of PISA 2009-2012. Washington DC: the World Bank.

5. Guide on Measuring Human Capital. (2016). Geneva: UNECE (UNITED NATIONS ECONOMIC COMMISSION FOR EUROPE). 
6. https://www.cedefop.europa.eu. (n.d.). Retrieved from https://www.cedefop.europa.eu/en/news-and-press/news/europe2020-employment-performance-monitor-and-benchmarks

7. Human Capital Project. (2021, March). Retrieved from https://www.worldbank.org/en/publication/human-capital

8. Human Capital: a theoritical and Empirical Analysis, with Special Reference to Education. (1975). New York: National Bureu of Education.

9. Labour Rorce Survey. (2013). Albania: INSTAT.

10. Recognising Non-Formal and Informal Learning. (n.d.). OECD.

11. National Strategy for Employment and Skills. (2014). Tirana: Ministry of Social Welfare and Youth.

12. WORKING IT OUT: CAREER GUIDANCE AND EMPLOYER ENGAGEMENT. (2019). Paris: OECD.

13. World Economic Forum. (2017). The Global Human Capital Report 2017. WEF.

\section{Websites:}

1. Ministry of Social Welfare and Youth (2016), , Republic of Albania, Tirana, https://www.al.undp.org/content/albania/en/home/library/pov erty/national-action-plan-persons-with-disabilities-2016-2020.html

2. Ministry of Social Welfare and Youth (2015), National Action Plan for Integration of Roma and Egyptians in the Republic of Albania, 20152020, Government of Albania,

3. Tirana, https://www.rcc.int/romaintegration2020/download/docs/201 5\%20Action_Plan_Albania\%202015\%202020.pdf/3e50b7165e9ea15 1a49dd99c0491ea64.pdf

4. Ministry of Social welfare and Youth (2014), National Employment and Skills Strategy 2014-2020, Republic of Albania, https://financa.gov.al/ëp-content/uploads/2018/09/NESSENG-8-1-15_final-version.pdf

5. MoESY (2018), OECD Review of Evaluation and Assessment: Country Background Report for Albania, Ministry of Education, Sports and Youth, Tirana 